\title{
The Lokan (Marsh Clam) Festival and the Rungus Ethnic Group Participant in Community-Based Aquaculture Program, North Borneo, Malaysia
}

Jalihah Md Shah, Diana Demiyah Mohd Hamdan, Rosazman Hussin \& Khairunesa Isa

To Link this Article: http://dx.doi.org/10.6007/IJARBSS/v11-i12/11537

DOI:10.6007/IJARBSS/v11-i12/11537

Received: 13 October 2021, Revised: 17 November 2021, Accepted: 30 November 2021

Published Online: 14 December 2021

In-Text Citation: (Shah et al., 2021)

To Cite this Article: Shah, J. M., Hamdan, D. D. M., Hussin, R., \& Isa, K. (2021). The Lokan (Marsh Clam) Festival and the Rungus Ethnic Group Participant in Community-Based Aquaculture Program, North Borneo, Malaysia. International Journal of Academic Research in Business and Social Sciences, 11(12), 1324-1336.

Copyright: (c) 2021 The Author(s)

Published by Human Resource Management Academic Research Society (www.hrmars.com) This article is published under the Creative Commons Attribution (CC BY 4.0) license. Anyone may reproduce, distribute, translate and create derivative works of this article (for both commercial and non0-commercial purposes), subject to full attribution to the original publication and authors. The full terms of this license may be seen at: http://creativecommons.org/licences/by/4.0/legalcode

Vol. 11, No. 12, 2021, Pg. 1324 - 1336

Full Terms \& Conditions of access and use can be found at http://hrmars.com/index.php/pages/detail/publication-ethics 


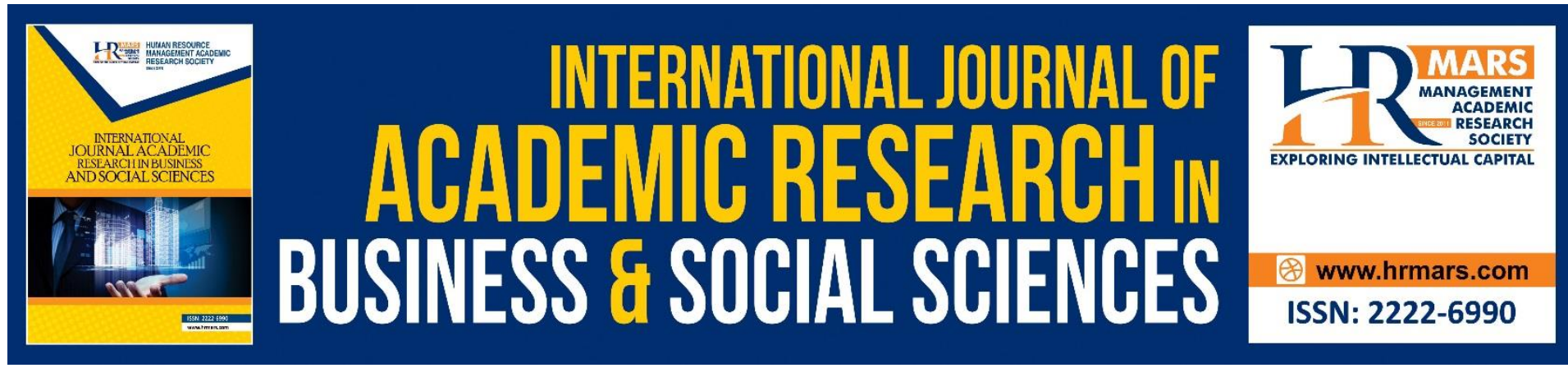

\title{
The Lokan (Marsh Clam) Festival and the Rungus Ethnic Group Participant in Community-Based Aquaculture Program, North Borneo, Malaysia
}

\author{
Jalihah Md Shah ${ }^{1}$, Diana Demiyah Mohd Hamdan², \\ Rosazman Hussin ${ }^{3} \&$ Khairunesa Isa ${ }^{4}$
}

${ }^{1}$ Faculty of Social Sciences and Humanities, Universiti Malaysia Sabah, Malaysia, ${ }^{2}$ Faculty of Science and Natural Resources, Universiti Malaysia Sabah, Malaysia, ${ }^{3}$ Borneo Institute of Indigenous Studies, Universiti Malaysia Sabah, Malaysia, ${ }^{4}$ Centre for General Studies and Cocurricular, Universiti Tun Hussein Onn Malaysia, Malaysia

\begin{abstract}
Communities undertake various strategies to ensure that the development programs introduced to them can sustain. For participants of the Lokan (Marsh Clam) Acquaculture Project in Kopunadan Village, Matunggong, North Borneo which consists of the Rungus ethnic group, Lokan Festival is one of the platform for income sustainability among the program participants. When first introduced in 2016, Lokan Fiesta managed to bring together the Kopunadan villegers and attracted the surrounding communities to make this festival a success. Filling the festival raised lokan as the main product of the festival through lokan burning activities, experience collecting lokan at the mangroves, sale of raw lokan, lokan cooking competition and lokan-based children's fashion show. In addition, the Rungus cultural performances such as dancing and singing were also performed. The community also wears traditional dress and displays the cultural product for the gaze of visitors. Thus, the Lokan Festival has become a community meeting ground, a location to generate side income, especially the participants of the Lokan Aquaculture Project and at the same time promote the culture of the Rungus ethnic group.
\end{abstract}

Keywords: The Rungus, Lokan (Marsh Clam) Festival, Community Development, Community Participation

\section{Introduction}

The active participation of the community in poverty eradication efforts is one of the important indicators to the achievement of goals and success of development programs. In Malaysia, many projects have been introduced by development agencies are to increase the income and quality of life of communities, especially in rural areas. However, there are concerns among government agencies about the community's ability to manage development programs independently (Abdul Razzaq \& Mustafa, 2014) after the project introduction period is over. To what extent is the community able to ensure that the projects 
introduced to them can sustain? The fact is, the achievement and the failure of a development program essentially depends on the willingness and commitment of the community to continue the project even without full monitoring by the implementing agency. To that end, the community undertakes various strategies to ensure that the development programs introduced to them can be continued. This is because if the community feels that the development program belongs to them (Tambi, et al., 2018), then various efforts will be made to ensure that the development program can not only survive but can be developed in the future. Accordingly, this article discusses two main research objectives:

- $\quad$ The participation of the Rungus ethnic group in Lokan (Marsh lam) Aquaculture Program; and

- $\quad$ The efforts made by the Rungus ethnic in Kopunadan Village, Matunggong, North Borneo to sustain the lokan breeding program.

This community created the Lokan Festival as a form of platform enable the sustainability of this development program but at the same time also highlights the Rungus culture. The uniqueness of this ethnic group culture is combined with economic activities through the Lokan Festival which was first introduced in 2016. This festival has successfully brought together communities members of the Kopunadan Village and attract other villages to attend this festival. The party, which was originally to diversify activities to promote lokan, eventually became a place to showcase the material culture of the Rungus ethnic group for visitors gaze.

\section{The Rungus and Community Development Program Literature Review}

The Rungus ethnic group is one of the indigenous ethnic groups of Sabah (North Borneo) that are included in the Dusun clump (Ong, 2006) or Kadazan Dusun (Low \& Abdullah, 2014). The majority of these ethnic groups are Christians and their places of residence are concentrated in the north of Sabah, namely Kudat, Kota Marudu and Pitas. Kudat district is considered as the original settlement of the Rungus ethnic group, especially Matunggong (Ong, 2006). Around the Matunggong Sub-District, the Rungus community tends to see themselves as Momogun i.e. local people or locals (Ong, 2006) who are different from other ethnic groups in Sabah (Low \& Abdullah, 2014). Migration due to economic factors, marriage and education has caused the Rungus ethnic group to be found outside Northern Sabah, including the Peninsula Malaysia and Sarawak (Porodong, 1997).

Traditionally, the economic activity of the Rungus community is farming (Porodong, 1997; Bahauddin et al., 2015) and is even recognized as the greatest farmer in the Borneo Islands (Appell, 1986). The main agricultural produce of the Rungus ethnic is hill paddy (Appell, 1972) in addition to short -term crops such as corn, sweet potatoes, bananas and sugarcane as side crops (Porodong, 1997). Animal husbandry such as chickens, buffaloes and pigs are also practiced either for food purposes, wedding delivery or to settle sogit (Porodong, 1997). Fishing activities are also done using traps or fishing rods (Appell, 1972). Although the Rungus ethnicity is well known for hill paddy cultivation (Appell, 1972; Porodong, 1997) but there are records in the previous literature about the involvement of this community in fishing activities (Appell, 1972). Nevertheless, studies on the involvement of these communities in fisheries are still limited when compared to studies of culture (Low \& Abdullah, 2014), lifestyle (Paul, 1997) and settlement (Ong, 2004; Bahauddin et al., 2015) this community. In an effort to 
reduce poverty, especially in rural areas, the Sabah state government had developed rubber or oil palm plantation projects (Kodoh et al., 2016). As a result, there is a shift in employment among the rural population from marine based economic activities to rubber or oil palm plantations which are considered more stable in terms of income compared to fishing activities.

The implementation of community development generally gives hope for positive changes in life among community members. Community involvement in development activities carried out is able to build community capacity through the increase of knowledge, skills and experience (Salim \& Abdul Samah, 2020). Generally, there are three approaches in community development namely (i) top-down; (ii) bottom-up and (iii) cooperation (Abd. Wahab, 2015; Abdul Samah, 2011). In general, community development can be defined in a variety of ways (Philips \& Pittman, 2009) and depends on the location as well as culture of the community involved (Sabran, 2003). As a result, some see community development as a process, method, program or movement (Sanders, 1989). In Malaysia, community development programs were introduced with the aim of freeing the rural community from the shackles of poverty (Abd. Wahab \& Abu Bakar Ah, 2017). The involvement and ability of the community to manage development projects is an important indicator in determining the success of a program.

Community development is a relentless process that takes place in a community even though its members have reached a level of empowerment. While the success or failure of community development is largely determined by determination, hard work and community involvement at the local level (Rashid, 2011; Sabran, 2003; Sanders, 1989). Therefore, the positive reaction and response of the community is important to determine the success of a development program. Sabran (2003) explained that community development is a vigorous effort by the parties involved, especially the community to improve their living standards and quality of life. Without the commitment of community members, then involvement in development programs is meaningless. This is because development cannot move on its own without the involvement of the community which is the party closest to the development program and designed specifically for them.

Community participation, whether through voices such as opinions or being involved in decision-making should not only be heard by development agencies but should also be taken into account in planning and implementing development. This is because the development introduced is for poor communities (Cernea, 1996). On the other hand, development agencies are intermediaries for the community to ensure that the positive impact and benefits of development are felt for the development of the country as a whole. Involvement is a dynamic process, therefore, it is not surprising if there is a tendency for a decrease or increase in the degree of involvement over time (White, 1996). All stakeholders need to be prudent to ensure that their interest and involvement is at an optimal level in order to achieve development goals holistically. Cooperation between these stakeholders is important to ensure that the development runs smoothly and continuously regardless of the location and form of a program introduced (Sharif \& Lonik, 2018). 


\section{Location of Studies}

Mangrove swamps can be used as a source of livelihood and main income generation for communities, including the Rungus community in Kopunadan Village. This 600 -acre village is located in the small district of Matunggong overlooking Teluk Marudu, Kudat, Sabah. At the vicinity of Marudy Bay, Kopunadan Village is located on latitude $6^{\circ} 41^{\prime} 4.030$ " $\mathrm{N}$ and longitude $116^{\circ} 45^{\prime} 25.239^{\prime \prime} E$ which is only 2 kilometers away from the coastline. When the study on this community was conducted, the total population of Kopunadan Village was 412 people, most of whom were Rungus. The name of this village is taken in conjunction with the name of a type of tree that grows in the village area which also has traditional medical value for the Rungus ethnic group, namely 'Kopunadan'. Although relatively, Kopunadan Village has just been opened and explored, the residents of this village still practice the family way of life in longhouses and there are still some house structures built according to the design of Rungus ethnic houses.

\section{Research Methodology}

Data from this qualitative study were collected through participatory observation techniques and in-depth interviews. In addition, samples of mangrove swamp water in Kopunadan Village was taken to test the in-situ parameters of the water while lokan was collected to find out the size and type of lokan reared. The study was conducted in three phases namely (i) January 2017; (ii) March 2017; and (iii) August 2017. The researcher followed the respondents to visit the mangrove swamp area of Kopunadan Village located in Teluk Marudu, Kudat, Sabah. The selection of Kopunadan Village as the study location is because the area was the first Lokan Breeding Project in Kudat introduced by the Sabah Department of Fisheries Matunggong branch. Typically, lokan collection activities in this district are carried out conventionally throughout the mangrove swamp area (Mojiol et al., 2016). Meanwhile, the focus of aquaculture projects by the agency previously focused on fish farming and seaweed cultivation projects (Sabah Department of Fisheries, 2013). Thus, this study can be a project model and a measure of the potential and relevance of such community development programs implemented elsewhere in the future or vice versa. This is because the lokan caged project is capable of being a safe food source provider to consumers.

In addition, the researchers also conducted participatory observations by conducting lokan collection activities in the breeding area. With this, researchers directley can see the cage area and experience the lokan collecting carried out in the magrove. Researchers have participated in the Lokan Festival twice, which were held in 2017 and 2018. In year 2017, this festivel held in the Kopunadan Cultural Hall buit of boards and bamboo which is located on a hill near the lokan caged area. During the festival, the researchers had the opportunity to grilled the collected lokan and ate grilled and raw lokan. To obtain detailed data, an interview session was conducted with five informants consisting of the Kopunadan Lokan Aquaculture Chairman, Chairman of Kopunadan Village Development and Security Committee, two project participants and Sabah Department of Fisheries Officer Matunggong branch. A set of structured interview questions were prepared and the questions posed to the respondents according to specific sub-themes such as the background of involvement in the project, lokan collection activities and market, problems and challenges faced while participating in the Lokan Breeding Project and Lokan Festival activities. Each interview session was recorded and lasted for 30 minutes to an hour. The interview data were then transcribed into document form and analyzed according to sub-themes. 


\section{Findings and Discussion}

\section{The Participation of Rungus Community in Lokan (Marsh Clam) Aquaculture Program}

Locan collection activity is one of the subsistence economic activities of the Rungus community in Kudat, especially the residents of Kopunadan Village. Fishing activities of aquatic life in mangrove swamps have contributed around RM432.75 per month to community household income in Kudat (Mojiol et al., 2016). This shows that mangrove swamps can be used as a source of livelihood and main income generation for the community. Kopunadan Village is located less than one kilometer from the mangrove and the sea area, has caused most of the community to choose to engage in fishing activities as a livelihood, including collecting lokan (marsh clam). Along the coast of Kopunadan Village adjacent to Marudu Bay is protected by mangrove area that rich in natural resources which provide food and economic resources to the communities.

The land transport network is still in a red dirt road after entering Jalan Sebayan from Jalan Tun Hussien Onn which connects Kudat and Kota Marudu. Therefore, there are still many residents of Kopunadan uses water transport for movement to other areas. The village jetty was completed in 2017 to make it easier for residents to bring their agricultural product for sale to the agricultural produce collection centers and tamu. Tamu is a local market which the indigenous of North Borneo (Sabah) markets their crops, forest products, livestock, catches, handicrafts and traditional drinks. Currently, most all districts in the state of Sabah have tamu operating on certain days. According to Porodong (1997), before the currency was widely used, barter trade was done in the tamu. Although money now plays an important role in any transactions, there are a small number of traders in Matunggong who still practice bartering among business partners.

Half of the Kapunadan population still practices subsistence farming such as paddy and banana cultivation. Only hill paddy is grown in Kopunadan due to lack of irrigation system facilities, limited flat land and the surface of the area is mostly hilly. There are also villagers who work on small rubber plantations for their livelihood. Apart from agriculture, the Rungus community in this village is also involved in the fisheries sector to increase their economic resources. Mangrove forest area in Kopunadan Villlage is located within the protection area of the Forestry Department and is part of Tun Mustapha Marine Park, which is a marine protected area, therefore, trees are prohibited from being cut down. The villagers go down to the sea to catch fish and crustaceans for their own food and generate side income.

Before the lokan breeding project was introduced, the Rungus community in Kopunadan collects lokan and does not have a systematic method of storing. Lokan is collected everywhere in the Marudu Bay area and the villagers had to discarded the damaged lokan due to failure to be sold. However, the situation was different when the Lokan Aquaculture Project was introduced in 2014 to this community. This project is one of the Aquaculture Projects by the Sabah Department of Fisheries (Matunggong) Branch. The introduction of this program is aims to increase the income of the rural population through aquaculture projects. Rungus community in Kopunadan Village is a pilot participant of the Lokan Aquaculture Program in Kudat. All participants in this project are fishermen and carry out activities to collect lokan as an income generating resource. The Rungus community in this village is involved in selling lokan at Matunggong Tamu every Thursday. 
At present, there are 11 participants involve in Lokan Aquaculture Project in Kopunadan Village. The pilot participants involved in this project were given assistance in terms of equipment and training by the Sabah Department of Fisheries. Assistance in the form of equipment for building cages is such as nets, bulian poles, tie cables, ropes, boards, nails and chainsaws. While a small boat that can only carry two people, a five-horsepower outboard engine and a trolley are provided to carry out the lokan collection work and bring it out of the aquaculture area to the jetty. Apart from that, wood was also given to the participants to build a wooden bridge about 200 meters long. In addition to equipment aids, basic training was provided to participants for five days. Among these basic forms of training is the technique of building a lokan cage.

Although this project is a group project, but each participant has their own cage built in collaboration among participants and family members in the mangrove area located in Marudu Bay. The participants also shared a boat and engine to the cage area. Even so, participants only collected lokan in their own cages. The area of the pilot group cage was 60 $x 60$ square feet. The distance of this lokan breeding area is 0.7 kilometers from the road and climb a hill is needed to reach the mangrove area. According to the respondents, their had to carry outboard engines and trawls every time to the sea. This remote location does not prevent participants from undertaking this aquaculture project because according to the informant, it is a "preferred source of income". This is because 70 percent of the economic activities of the villagers are based on the sea while the rest are activities on land such as agriculture and government/private work.

The mangrove in the area are free from any form of pollution. In fact, tests on water samples from the location of project area found that the average in-situ parameters of water were 6.66 ph while salinity $(0 / 00)$ was 3.71 , dissolved oxygen $(\mathrm{mg} / \mathrm{L})$ was 3.73 and electrical conductivity $(\mathrm{ms} / \mathrm{cm})$ was 14.04 . With this, the environmental factors of $\mathrm{pH}$ and salinity as well as the mangrove tree canopy area covered in the mangrove of Kopunadan Village is in an environment suitable for lokan breeding. Samples on collected lokan found two types of lokan bred in participants' cages namely polymesoda erosa and polymesoda expansa. However, for the participants, these two types of lokan are differentiated according to gender, namely male and female lokan. There are three groups of lokan based on size found in breeder cages i.e. small (less than $50 \mathrm{~mm}$ ); medium (50 mm to $70 \mathrm{~mm}$ ); and large (over 70 $\mathrm{mm})$. Although, the Rungus community in Kopunadan Village do not have scientific knowledge of lokan species, yet they have a basic knowledge of the nature and nutrients of this marine species. This Lokan Aquaculture Project is a form of community-based management undertaken by the villagers in an environmentally friendly and sustainable manner. One of the issues faced by the community and project participants is the question of sustainability of this program in the future. To what entend this program can survive because as shown in previous studies, many community development programs fail to go ahead after development agencies hand over projects entirely to be run by the community (Abdul Razzaq \& Mustafa, 2014). According to Mr. Shafik, Chairman of Kopunadan Village Development and Security Committee who also participant of Lokan Aquaculture Project:

"I thought back and forth, how do I want to make lokan project sustain in Kopunadan Village? We want this project to last and continue to provide income to the participants. I don't want this to be an abandoned project. So I 
think, there should be another program that can support this project and help spread the visibility of lokan farming, attract people out from this village to come and buy the lokan from our caged. I find the best way to attract visitors is to have a lokan festival which with cultural performances".

The study on the Rungus community in Kopunadan found that the leadership at the community level as well as project participants were committed towards the projects their involved. The introduction of Lokan Festival is vital in order to sustain the aquaculture program which at the same time promote the Rungus cultural activities.

\section{Lokan Festival: Efforts to Promote Lokan and Rungus Ethnic Culture}

Lokan Aquaculture Project in Kopunadan Village is successful because the community is expanding the concept of lokan farming beyond economic activities alone. The idea of organizing the Lokan Festival was raised by the project participants who are also the Chairman of Kopunadan Village Development and Security Committee. According to Mr. Shafik, Lokan Festival was first organized in 2016. The desire to hold this festival was informed and approved by the Assistant District Officer and the Sabah Department of Fisheries. However, the community is facing the issue of funding for the festival. As a result, the Lokan Festival in year 2017 was postponed several times before the final date of 12 August 2017 was determined. Generally, the Lokan Festival is recommended to promote lokan to outsiders. Lokan Festival is seen as one of the alternatives for lokan independent collector and lokan project participants to market the lokan in addition to maintaining the current marketing methods by sending lokan to the nearest market or taking orders from other areas.

The Lokan Festival was introduced to promote this aquatic life which was collected by the Kopunadan communities especially participants of the Lokan Aquaculture Project. According to the Lokan Aquaculture Project participants, many residents in the Marudu Bay area make lokan collecting activities as one of the household economic resources. This leads to intense competition to market the lokan. Therefore, other mechanisms need to be done to ensure that the lokan from Kopunadan is known and can compete with the lokan that is in the market. The Lokan Festival has put lokan aquaculture visible and succeeded in attracting the local community to participate in economic development programs. The proof is, since its introduction, the Lokan Festival has given a new dimension to lokan collecting activities. For example, lokan can be bred and stored systematically. More villagers are applying to participate in aquaculture projects since the Lokan Festival was introduced in Kopunadan Village. In the meantime, the success of the participants of this project in organizing the Lokan Festival has caused lokan farmers in other villages to also express a desire to hold a similar festival. This was, for example, voiced by the Chairman of Naboh Village Development and Security Committee, the Kopunadan nearby village who has planned to hold a Lokan Festival in her village.

At the same time, the Lokan Festival has become a method to highlight the Rungus ethnic culture. For the organizers, the activities during the festival should be accompanied by the highlighting of cultural elements that are the strength of the Rungus ethnic group. The combination of economic and cultural activities is expected to attract the local community and foreign visitors to join the festival. Indirectly, the culture and traditions of the Rungus ethnic community can be highlighted during the festival. During the Lokan Festival, the 
organizers conduct various activities that are open to the local community. The activities in the festival were also attended by residents from surrounding villages, elected representatives (YB) and government agency officials. Generally, Lokan Festival activities are divided into two forms, the first is a lokan-based competition and the second is a performance of Rungus ethnic culture. The organization of the first (2016) and second (2017) Lokan Festival shown visitors being taken to visit the lokan breeding site and a lokan collecting competition was conducted. However, due to the change of festival location from Kopunadan Cultural Hall which is located near the mangrove, visits to the lokan breeding area were not undertaken during the Lokan Festival in 2018. Usually, the Lokan Festival lasts for a day from 9.00 am to $6.00 \mathrm{pm}$. During the festival, visitors will be treated to a free grilled lokan.

Photo 1. Temporary Stall Built during Lokan Festival for Selling Community Local Product such as Coconut Oil and Raw Lokan

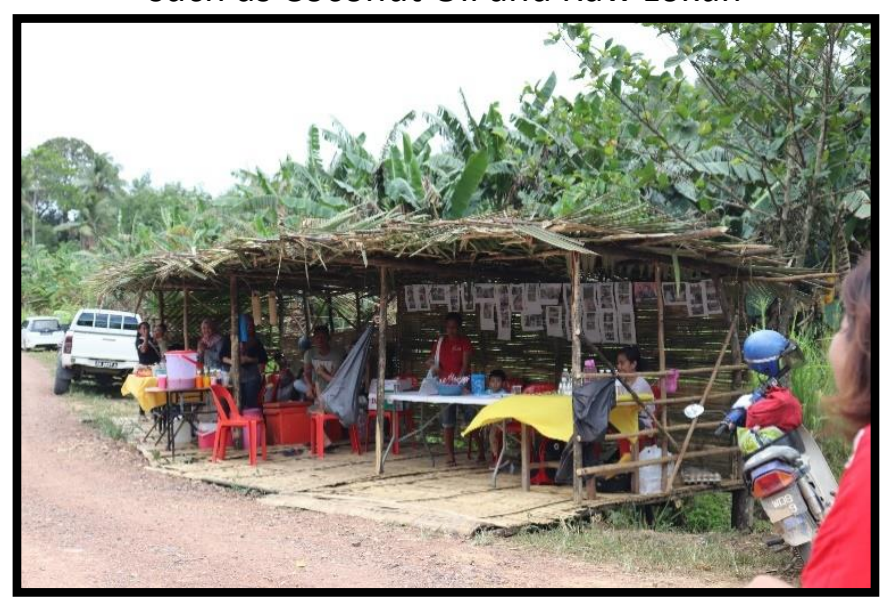

In an effort to ensure lokan becomes a choice for daily consume, lokan-based competitions are held in this festival. The competition was organized involving all of age groups and genders among the Rungus community living around Kopunandan. Women are involved in lokanbased cooking competitions and various forms of lokan menu are competed such as lokan rendang, sambal lokan and lokan soup. The food is prepared at the participant's homes and brought to the festival to be judged by a panel of jury consisting of VIPs. The consumption of a decoction of lokan and raw papaya in the Rungus community is usually given to women who have just given birth to increase their breast milk. For that, women will usually pick up the lokan after their daughter gives birth. Apart from being boiled, lokan can also be eaten raw, especially after drinking alcohol. As a result, the demand for lokan increases during the festive season of Christmas and Kamaatan Festival (Harvest Festival).

Photo 2. Judges Measured the Size of Lokan to Find the Largest Lokan

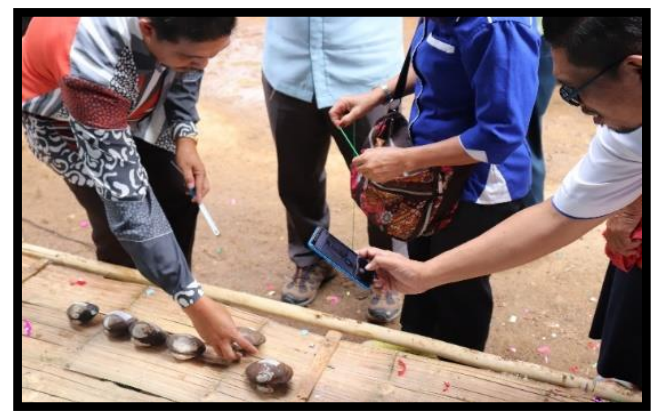


In addition to the lokan cooking competition, a competition to find the largest lokan size was also held among the project participants and lokan collectors. This competition which is joined by men and women usually collected their lokan the day before the festival is held. Lokan will be displayed and measured by the judges to find the three winners who manage to collect the largest lokan [see Photo 2]. The final activity of the lokan-based competition was a decorated children's clothing competition featuring lokan shells as clothing motifs. Some of the children wore traditional Rungus ethnic dress and modern dress. Lokan shells are used as decorations on the head, clothes and shoes. All winners in the competition organized in this Lokan Festival will receive prizes in form of hamper.

Photo 3. Children Perfoming Mongigol Sumundai Dance during Lokan Festival

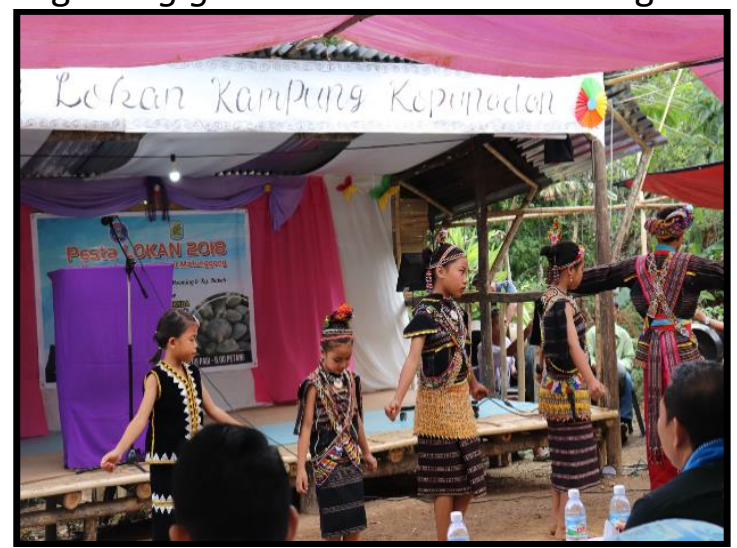

Incorporating elements of Rungus ethnic culture through cultural performances has made this Lokan Festival unique and not focused on socio-economic events alone. Two Mongigol Sumundai dance performances accompanied by gongs and drums were performed by adults and children [see Photo 3]. In addition, song performances in Rungus are also delivered by male and female singers in this community. Throughout the festival, the elders of the Rungus community were seen wearing traditional Rungus clothing. The festival is considered by this older generation to be just as important as other festivities that need to highlight the Rungus ethnic identity.

Photo 4. Bead Chain produced by Rungus Women Sold during Lokan Festival

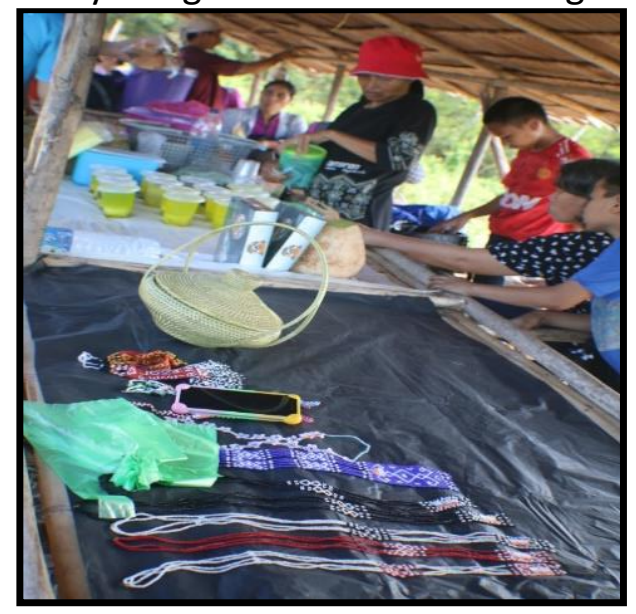

The involvement of the Rungus community in the Lokan Festival is also manifested in the form of the sale of products produced by this community. The site of the stall erected from nipah leaves houses temporary lots selling lokan, fish, food, Rungus ethnic handicrafts and virgin coconut oil. Necklaces and bracelets made of beads made by Rungus women themselves are 
sold at cheaper prices than the market. For example, a bead chain in the market priced at RM25.00 each is sold at a price of RM15.00 only [see Photo 4]. There were also women making beaded chains in the stalls when the party took place.

\section{Conclusion}

The organization of the Lokan Festival by the Rungus community who are participants in the Lokan Aquaculture Project has opened up the potential of this activity through lokan collection activities alone. This project has become a starting point to promote the Rungus ethnic culture through the Lokan Festival. In other words, economic activity is intertwined with cultural activity. Such indirect relationships cause participants to feel responsible and attached to the development project involved due to the connection with the culture that is able to encourage a sense of belonging. The participants 'understanding of the development project about their purpose and role causes the community to know the limits of the assistance given to them. With that, the community can be prepared for the challenges that will arise after the development agency exits the project. Rungus community in Kopunadan Village understands that after the equipment is provided, they have to handle the project without having to rely on the Sabah Department of Fisheries. Even this community is also aware that the projects introduced are aimed at expanding existing sources of income. Therefore, those who need to find lokan seeds themselves, find markets inside and outside the village as well as introduce lokan-based activities such as the Lokan Festival for the sustainability of the projects involved. The success shown by the Rungus community which is a pioneer participant has attracted the interest of local community members to get involved in the lokan breeding project. This is referred to by Smith (1998) as extending the collective socioeconomic benefits to community members. The first Lokan Festival of its kind held in the Kudat area is considered to be a benchmark for the next organization and is seen as a starting point to promote the economic and cultural activities of the Rungus ethnic group. While the desire of community members to be involved in the Lokan Aquaculture Project is an indication that this development project is well received by the community and the potential of this project can be preserved. In the long run, this locan breeding area has a potential to be developed into one of the ecotourism and cultural products in the Kudat area, North Borneo, Malaysia.

\section{References}

Abd. Wahab, H. (2015). Pendekatan Pelaksanaan Pembangunan Komuniti. Dalam Zakiyah Jamaluddin (editor). Perancangan dan Pembangunan Komuniti. Sintok: Penerbit Universiti Utara Malaysia.

Abd. Wahab, H., \& Abu Bakar Ah, S. H. (2017). Perkembangan Pendekatan Pembangunan Komuniti Luar Bandar di Malaysia. SEJARAH: Journal of the Department of History. Volume 15, No. 15, November 2017, halaman 57-79.

Abdul Razzaq, A. R., \& Mustafa, M. Z. (2014). Pembangunan Keupayaan Komuniti Menerusi Pendekatan Pembelajaran Berasaskan Pengalaman (Experiential Learning Approach): Pengalaman di Miso Walai Homestay, Kinabatangan, Sabah. Prosiding CiE-TVET.

Abu Samah, A. (2011). "Teori dan Amalan Pembangunan Komuniti dalam Perkhidmatan Kebajikan Malaysia". Dalam Khadijah Alavi, Rahim Md. Sail \& Nurul Akhtar Kamarudin. Pembangunan Komuniti: Membina Keupayaan Potensi Masyarakat. Serdang: Penerbit Universiti Putra Malaysia. 
Appell, G. N. (1972). Dusun Rungus. Ethnic Groups of Insular Southeast Asia. Vol. 1: Indonesia, Andaman Island, and Madagascar. In Frank M. LeBar (editor \& compiler). New Haven: Human Relations Area Files Press.

Appell, G. N. (1986). Social Anthropological Research among The Rungus Dusun: A Talk for Sabah Society. Sabah Society Journal, Vol. 8 (2), 194-208.

Bahauddin, A., Abdullah, A., \& Maliki, N. Z. (2015). The Rungus Longhouse of Sabah, Malaysian Borneo - A Dying Architechture. SHS Web of Conferences 18, 02002, 1-10.

Cernea, M. M. (1996). Social Organization and Development Anthropology. Environmentally Sustainable Development Studies and Monographs Series, no. 6. Washington D.C: The World Bank.

Kodoh, J., Sinusun, V., Liew, K. C., Maid, M., Lintangah, W., \& Mojiol, A. R. 2016. The contribution of rubber plantation to the socio-economic development: A case study on Kanibongan project-rubber smallholders community in Pitas, Sabah. International Journal of Agriculture, Forestry and Plantation 2:207-211.

Sharif, M. N., \& Lonik, T. K. 'A. (2018). Penglibatan Komuniti Tempatan dalam Keusahawanan Pelancongan: Kajian Kes Pulau Perhentian, Malaysia. Journal of Nusantara Studies (JONUS), Vol 3 (1) 103-119.

Salim, M. S. S., \& Abdul Samah, A. (2020). Penglibatan dan Pendayaupayaan Sosial dalam Kalangan Peserta Projek Yayasan Sejahtera di Malaysia. Community, Volume 6, Nomor 1, April 2020, halaman 71-82.

Mojiol, A. R., Lintangah, W., Ismenyah, M., Alamjuri, R. H., \& Jaafar, C. S. Z. (2016). Mangroves Forest Produce (MFP): Importance and contribution to the local communities at Banggi Island Malaysia using Free Listing Technique. International Journal ofAgriculture, Forestry and Plantation, 3(6), 89-94.

Ong, P. L. (2006). Rumah Panjang Tradisi Rugus dalam Arus Pembangunan: Perbezaan Pengertian. Akademia 68 (Januari), 43-64.

Philips, R., \& Pittman, R. H. (2009). Measuring Progress: Community Indicators, Best Practices, and Benchmarking. In Philips, R. \& Pittman, R. H (Editor). An Introduction to Community Development. London: Routledge.

Porodong, P. (1997). Kemiskinan di kalangan Kaum Rungus di Daerah Kudat, Sabah. Tesis Sarjana. Universiti Malaya.

Rashid M. Z. (2011). Potensi dan Cabaran Pembangunan Komuniti di Malaysia. Dalam Khadijah Alavi, Rahim Md. Sail \& Nurul Akhtar Kamarudin (Editor). Pembangunan Komuniti: Membina Keupayaan Potensi Masyarakat. Serdang: Penerbit Universiti Putra Malaysia.

Sabah Department of Fisheries. (2013). Laporan Tahunan Bahagian Khas Tahun 2012. Kota Kinabalu: Sabah Department of Fisheries.

Sabran, M. S. (2003). "Model Pembangunan Komuniti". Pertanika Journal Social Science \& Human. Vol. 11, No. 2, 135-145.

Sanders, I. T. (1989). The Concept of Community Development. In Cary, L. J. (Editor). Community Development as a Process. Columbia, Missouri: University of Missouri Press.

Smith, B. C. (1998). Participation Without Power: Subterfuge or Development?. Community Development Journal, Vol. 33, No. 3, 197-204.

Tambi, N., Che Kasim, A., Abdul Aziz, S. F., Idris, F., \& Selamat, M. N. (2018). Pengenalan. Dalam Pemerkasaan Komuniti Di Malaysia. Tambi, N., Manap, J., \& Abdul Aziz. S. F. (penyunting). Bangi: Penerbit Universiti Kebangsaan Malaysia. 
INTERNATIONAL JOURNAL OF ACADEMIC RESEARCH IN BUSINESS AND SOCIAL SCIENCES

Vol. 11, No. 12, 2021, E-ISSN: 2222-6990 @ 2021 HRMARS

White, S. (1996). Depoliticising Development: The Uses and Abuses of Participation. Development in Practise, Volume 6, Number 1,142-155. 